\title{
A Conceptual Analysis of the Knowledge of Prospective Mathematics Teachers about Degree and Radian
}

\author{
Abdulkadir TUNA ${ }^{1, *}$ \\ ${ }^{1}$ Educational Faculty, Kastamonu University, Kastamonu, Turkey \\ *Correspondence: Educational Faculty, Kastamonu University, Kastamonu, Turkey. E-mail: atuna2536@gmail.com
}

Received: May 23, 2013

Accepted: June 26, $2013 \quad$ Online Published: July 3, 2013

doi:10.5430/wje.v3n4p1

URL: http://dx.doi.org/10.5430/wje.v3n4p1

\begin{abstract}
This study examined the knowledge levels of prospective mathematics teachers about the concepts of degree and radian, which are among the angle measuring units that constitute the basis of trigonometry, and the relationships between those concepts. The study group consisted of 93 prospective mathematics teachers attending a state university in Turkey. Qualitative and quantitative research methods were used for data collection and analysis. 4 questions about the concepts of degree and radian were asked to the prospective mathematics teachers. The responses of the prospective teachers were categorized as correct and incorrect. Then, incorrect answers were divided into sub-categories by means of coding method and presented in tables. According to research findings, $40 \%$ of the prospective mathematics teachers defined the concept of degree correctly while approximately $90 \%$ made an incorrect definition of radian.
\end{abstract}

Keywords: mathematics education; prospective mathematics teachers; trigonometry

\section{Introduction}

It is a fact agreed by all educators that a teacher needs to have two types of knowledge before anything else in order to be successful in his/her professional life and contribute to the improvement of mathematical thinking of students (Shulman, 1986; Ball, 1991; Even, 1992; Watkins and Mortimore, 1999). The first type of knowledge is content knowledge which includes the knowledge of teachers about mathematical subjects. Content knowledge covers the understandings and perceptions of teachers regarding the epistemology of mathematical subjects as well as definitions, axioms, undefined concepts, proof methods, relations, rules and formulas related to these subjects (Ball, 1991; Watkins and Mortimore, 1999). The knowledge of teachers about the relationships between mathematical concepts is evaluated under this category, too. According to Shulman (1986), content knowledge deals with two main characteristics: (1) what is the mathematical concept? (2) why does this mathematical concept have such a nature?

Trigonometry is an important subject of mathematics in the sense that it both improves various cognitive skills of students and has a large area of use in the daily life. Having a considerable area of application in astronomy and geography in particular, trigonometry is commonly used in a wide range of fields including geometry, physics, optics, electricity, cartography, and maritime (Sağlam et al., 2007). Trigonometry provides transition from algebra to geometry. In addition, trigonometric functions and properties are used in many subjects including limit, derivative, integral, etc.

Trigonometry is an important concept in terms of the improvement of reasoning skills of students. According to the study carried out by (Tatar, Okur and Tuna, 2007), trigonometry is one of the subjects which students have most difficulty in understanding. Trigonometry is one of the primary subjects in which students experience learning difficulty (Durmuş, 2004). The incomprehension of the basic concepts making up trigonometry is one of the important reasons due to which students experience learning difficulty on the subject of trigonometry (Steckroth, 2007). The concept of angle and angle measuring units are among the important constituents of trigonometry. Radian is of importance for understanding trigonometric functions in particular (Akkoç, 2008). The comprehension of angle measuring units in trigonometry is the basis of success in trigonometry. The studies on the concept of radian, which is used for defining trigonometric functions, report that teachers, prospective teachers and students have certain learning 
difficulties about this concept (Fi, 2003; Orhun, 2004; Topçu, Kertil, Akkoç, Yılmaz, and Önder, 2006; Steckroth, 2007; Akkoç, 2008).

Having an important role in understanding trigonometric functions and thus trigonometry, the concept of radian is defined as "the ratio of the length of the arc faced by central angle to the length of the radius of the circle".

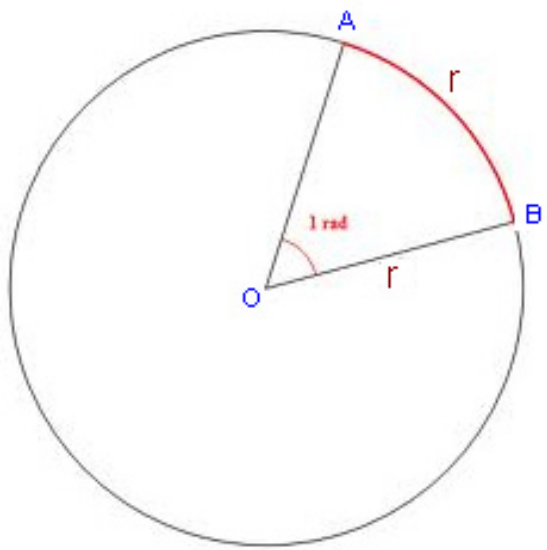

Figure 1: Definition of Radian

Since the concept of radian refers to the proportion of two lengths, it is expressed with a real number. Based on wrapping function, which includes wrapping a real number line around the unit circle, one radian angle measure is obtained for each real number. Mathematicians have defined trigonometric functions over real numbers in this way (Akkoç and Akbaş Gül, 2010). However, the degree that is obtained through the division of the unit circle into 360 equal parts is not used as the domain and range of trigonometric functions. The establishment of such a relationship between the concept of radian and trigonometric functions is of vital importance for the comprehension of trigonometric functions.

One of the important qualifications of a truly effective teacher is having sound mathematical knowledge (Farah-Sirkis, 1999). In addition, it is the prospective mathematics teachers who will teach the units of measurement that constitute the basis of trigonometry to their students in their future professional lives. From this perspective, it is considered significant to determine whether the prospective teachers know these concepts truly, what kinds of difficulties they experience in regard to these concepts, and at which points the difficulties experienced are most common.

\section{Method}

\subsection{Research Model}

Since this study aimed at examining thoroughly the conceptual understandings of prospective mathematics teachers concerning the concepts of degree and radian, non-experimental descriptive research method was employed. In general terms, descriptive research is a method whereby the characteristics of the groups or individuals under examination are presented statistically (McMillan \& Shumacher, 2010).

\subsection{Study Group}

The present study was conducted with 93 prospective teachers attending the $3^{\text {rd }}$ and $4^{\text {th }}$ grades at the Department of Primary School Mathematics Teaching of a state university in Turkey in the 2012-2013 academic year. The study group was made up of prospective teachers who succeeded in the courses of Analysis and Special Teaching Methods. In addition, individual interviews were conducted with 5 pre-service teachers so that rich data could be obtained.

\subsection{Data Collection}

4 open-ended questions were prepared in order to examine the conceptual knowledge of the prospective primary school mathematics teachers about the concepts of degree and radian, which were among the units of measurement. The questions were as follows: What do you understand from degree and radian? How many radians are there in a circle? What kind of a relationship is there between degree and radian? The opinions of 3 specialists who worked in the field of geometry teaching were taken during the preparation stage of questions. Data were collected from prospective teachers in written at the end of the fall semester of the 2012-2013 academic year. Prospective teachers were requested 
to answer the above-mentioned questions in approximately 45 minutes.

\subsection{Data Analysis}

Collected to determine the understandings of prospective mathematics teachers concerning the concepts of degree and radian, data were subjected to descriptive data analysis whereby the answers given to each question were analyzed in detail. Initial evaluation focused on the mathematical correctness or incorrectness of the answers given. Then, incorrect answers were divided into sub-categories. Obtained categories can be found in the findings section of this paper.

\section{Findings}

This section includes the findings about the conceptual knowledge of prospective mathematics teachers regarding the concepts of degree and radian.

Question 1: What do you understand from degree, which is an angle measuring unit? Write your opinions.

The Table 1 shows the findings pertaining to the definitions made by prospective teachers in regard to the concept of degree.

Table 1: Findings Pertaining to the First Question

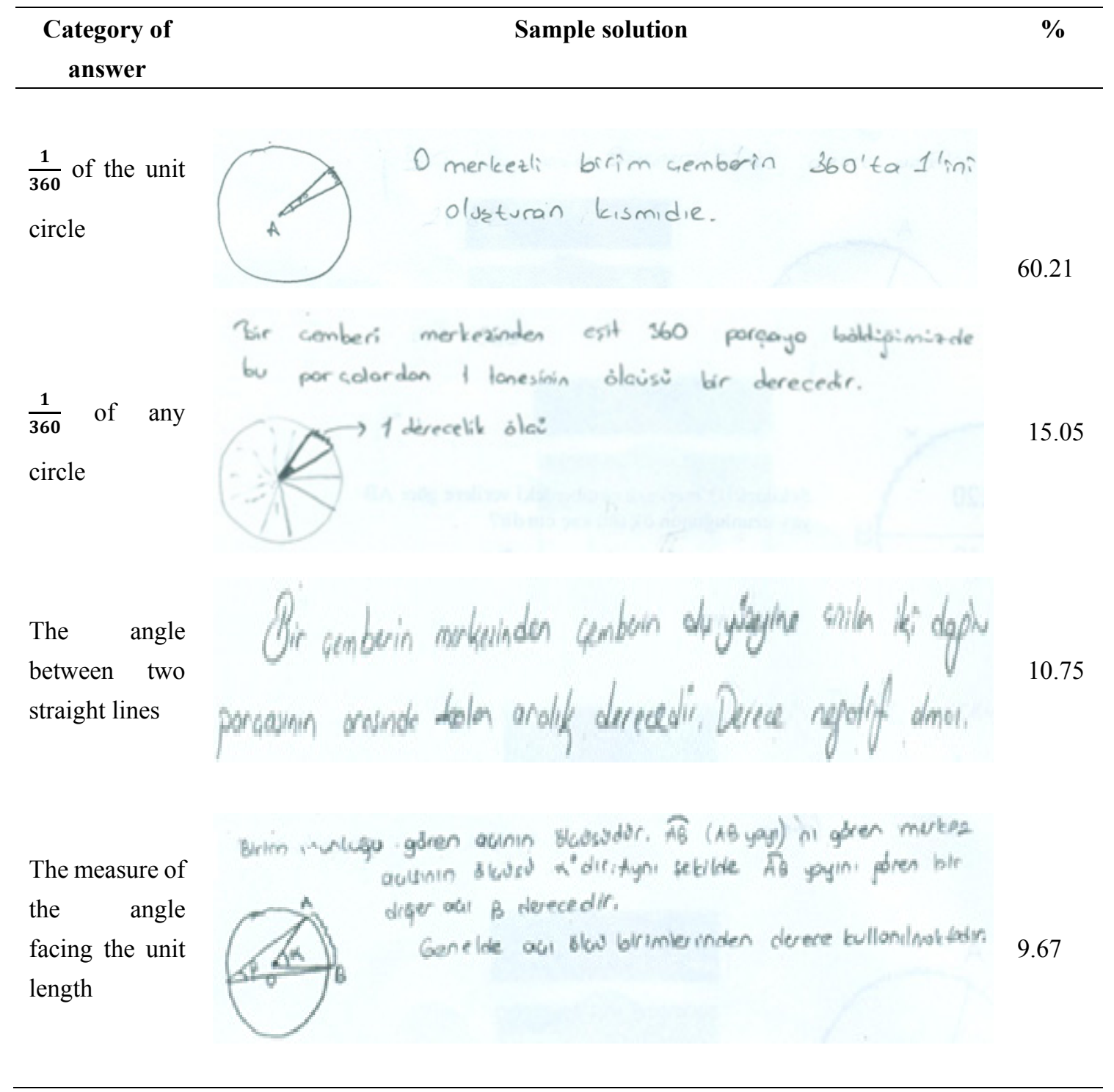




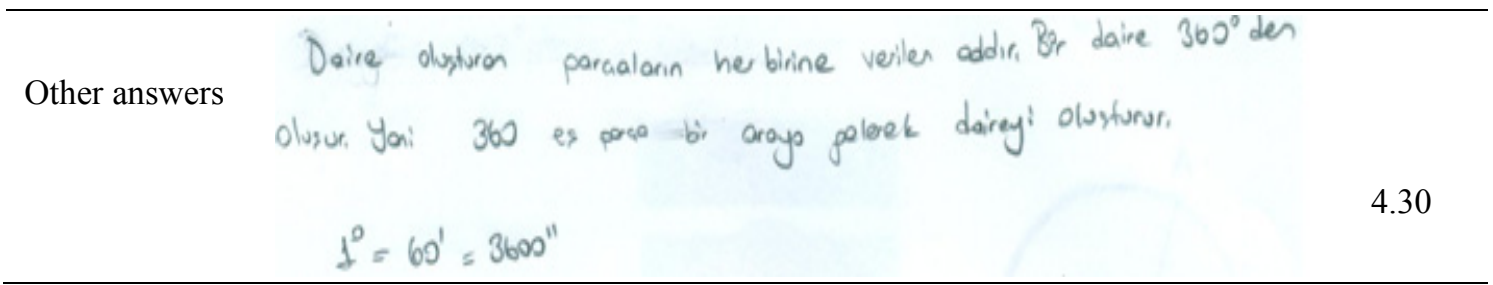

As is seen in the Table $1,60 \%$ of the prospective mathematics teachers made a correct definition of the concept of degree by saying, "it is $\frac{1}{360}$ of the unit circle" while $40 \%$ of the prospective teachers defined the concept incorrectly. The examination of such incorrect definitions reveals that $15 \%$ defined the concept by saying, "it is 1/360 of any circle", 10\% expressed it as "the angle between two straight lines", 9\% thought, "it is the measure of the angle facing the unit length", and $4 \%$ came up with other incorrect definitions.

Question 2: What do you understand from radian, which is an angle measuring unit? What kind of relationship is there between degree and radian? Justify it.

The Table 2 shows the findings pertaining to the definitions made by prospective teachers in regard to the concept of radian.

Table 2: Findings Pertaining to the Second Question

$\begin{aligned} & \text { Category of } \\ & \text { answer }\end{aligned}$
$\begin{aligned} & \text { The ratio of } \\ & \text { the arch faced } \\ & \text { by the angle to } \\ & \text { the radius }\end{aligned}$
$\begin{aligned} & \text { The } \\ & \text { expression of } \\ & \text { degree } \\ & \text { terms of } \pi \text { in }\end{aligned}$
$\begin{aligned} & \text { The unit of } \\ & \text { length } \\ & \text { degree of }\end{aligned}$




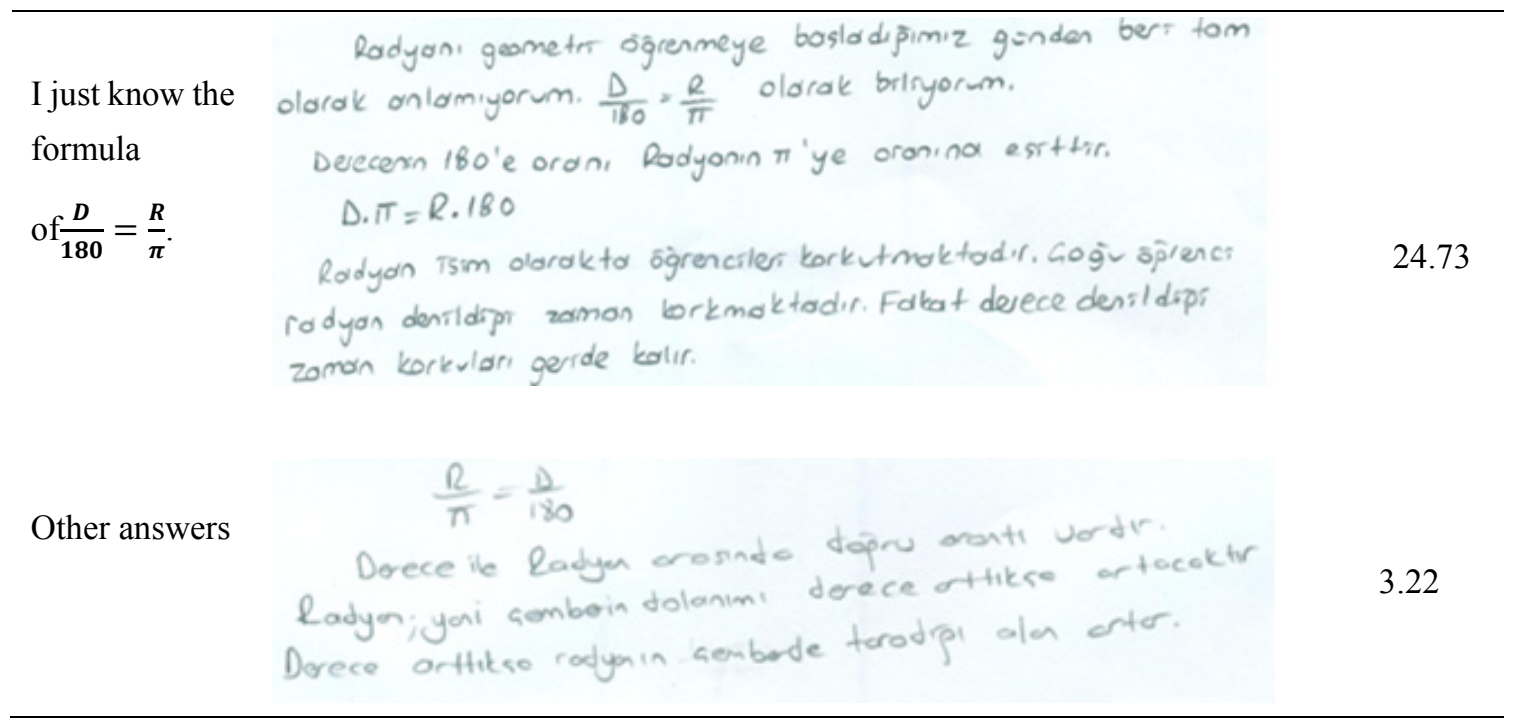

As is seen in the Table 2, only $8 \%$ of the prospective mathematics teachers made a correct definition of the concept of radian by saying, "1 radian is the ratio of the length of the arc faced by the angle to the length of the radius". Approximately $90 \%$ of the prospective mathematics teachers defined the concept incorrectly.

The examination of such incorrect definitions reveals that $39 \%$ defined the concept by saying, "it is the expression of degree in terms of $\pi$ ", $34 \%$ expressed it as "the unit of length of degree", and $24 \%$ said, "I just know the formula of $\frac{D}{180}=\frac{R}{\pi}$, I do not know what radian is". Although $40 \%$ of the prospective mathematics teachers know the relationship between degree and radian, only $8 \%$ know what radian is. This is a really remarkable finding.

Question 3: How many radians are there in a circle? Write your opinions.

The Table 3 shows the answers of prospective teachers in regard to the number of radians in a circle.

Table 3: Findings Pertaining to the Solution of the Third Question

\begin{tabular}{lcc}
\hline $\begin{array}{c}\text { Category of } \\
\text { answer }\end{array}$ & Sample solution & $\%$ \\
\hline
\end{tabular}

$2 \pi(6.28)$

$$
\begin{aligned}
& \text { 3. Sizce bir çemberde kaç radyan vardır? dụşüncelerinizi yazını. } \\
& \begin{array}{l}
\frac{D}{180}=\frac{R}{\pi} \quad \begin{array}{l}
\text { Bir cenberm oices }=360^{\circ} \text { dir. } \\
2 \frac{360}{160}=\frac{R}{\pi} \quad 2=\frac{R}{\pi} \quad R=2 \pi
\end{array} \\
\text { Bir conberde } 2 \pi=2,3,14=6,28 \text { radydn vardir. }
\end{array}
\end{aligned}
$$


2160

$\frac{1 \text { iderea } 6 \text { radyon ise }}{360^{\circ}}$
\[ x=2160 \text { radyon vardir- } \]
Yani bir cember de 2160 radyon vardir.

Other answers

3. Sizce bir çemberde kaç radyan vardır? düşüncelerinizi yazını. Bono pore alnon say, deperine gore fortlilit go'ster in. fortli soyiler olobilir.7.

As is seen in the Table 3, only $17 \%$ of the prospective mathematics teachers indicated the number of radians in a circle correctly by saying there are $\mathbf{2 \pi}$ radians in a circle. Approximately $80 \%$ of the prospective mathematics teachers indicated the number of radians in a circle incorrectly. $28 \%$ mentioned the number of radians in a circle as 360 , $11 \% \mathrm{~s}$ said 2160 , and $37 \%$ came up with other values.

\section{Question 4:}

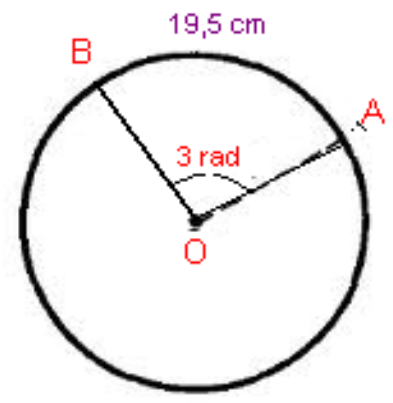

Based on what are given in the figure, what is the length $(\mathrm{cm})$ of the radius of the circle with $\mathrm{O}$ center?

The Table 4 presents the findings pertaining to the answers given by prospective teachers to the fourth question.

Table 4: Findings Pertaining to the Fourth Question

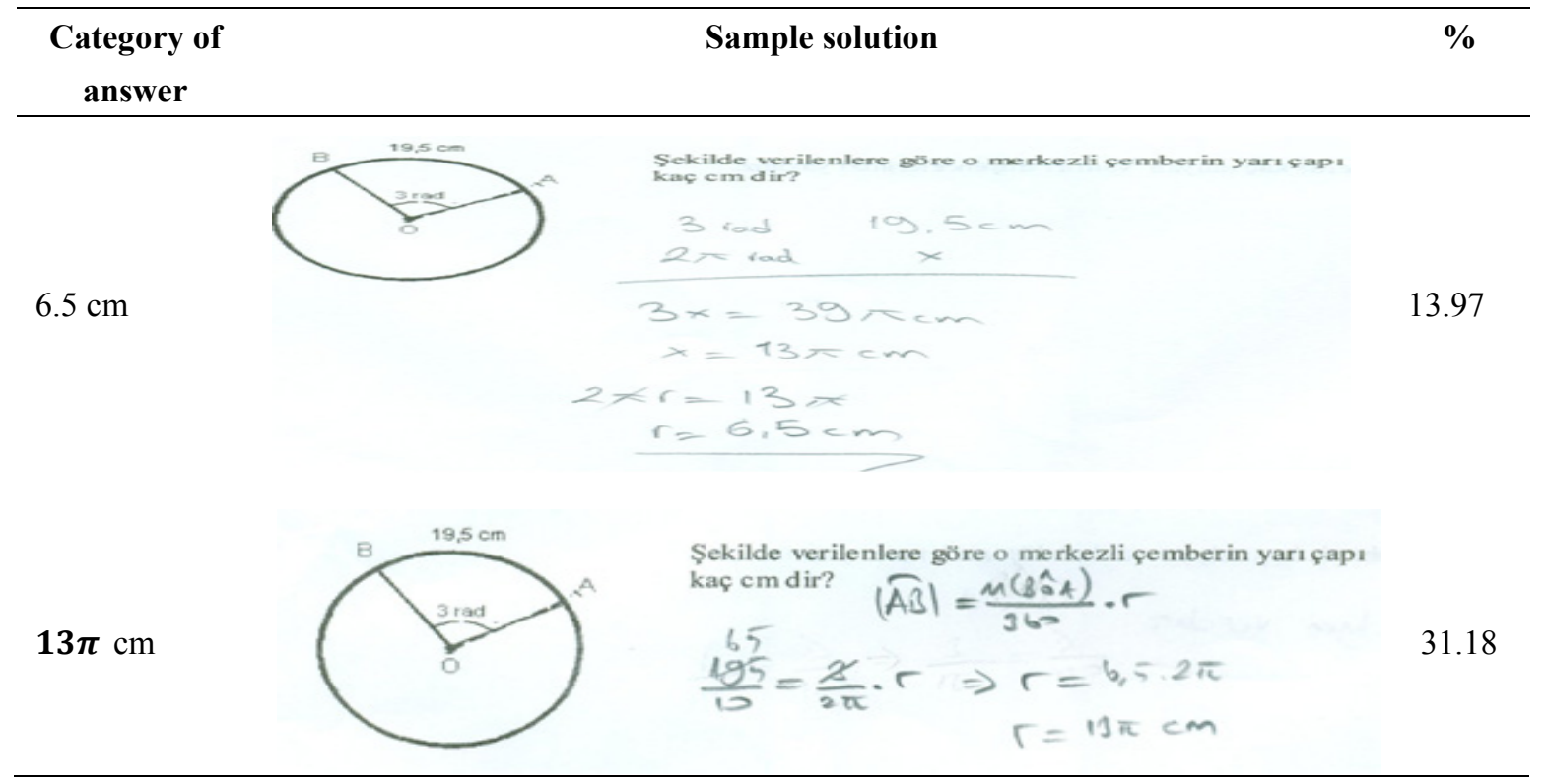




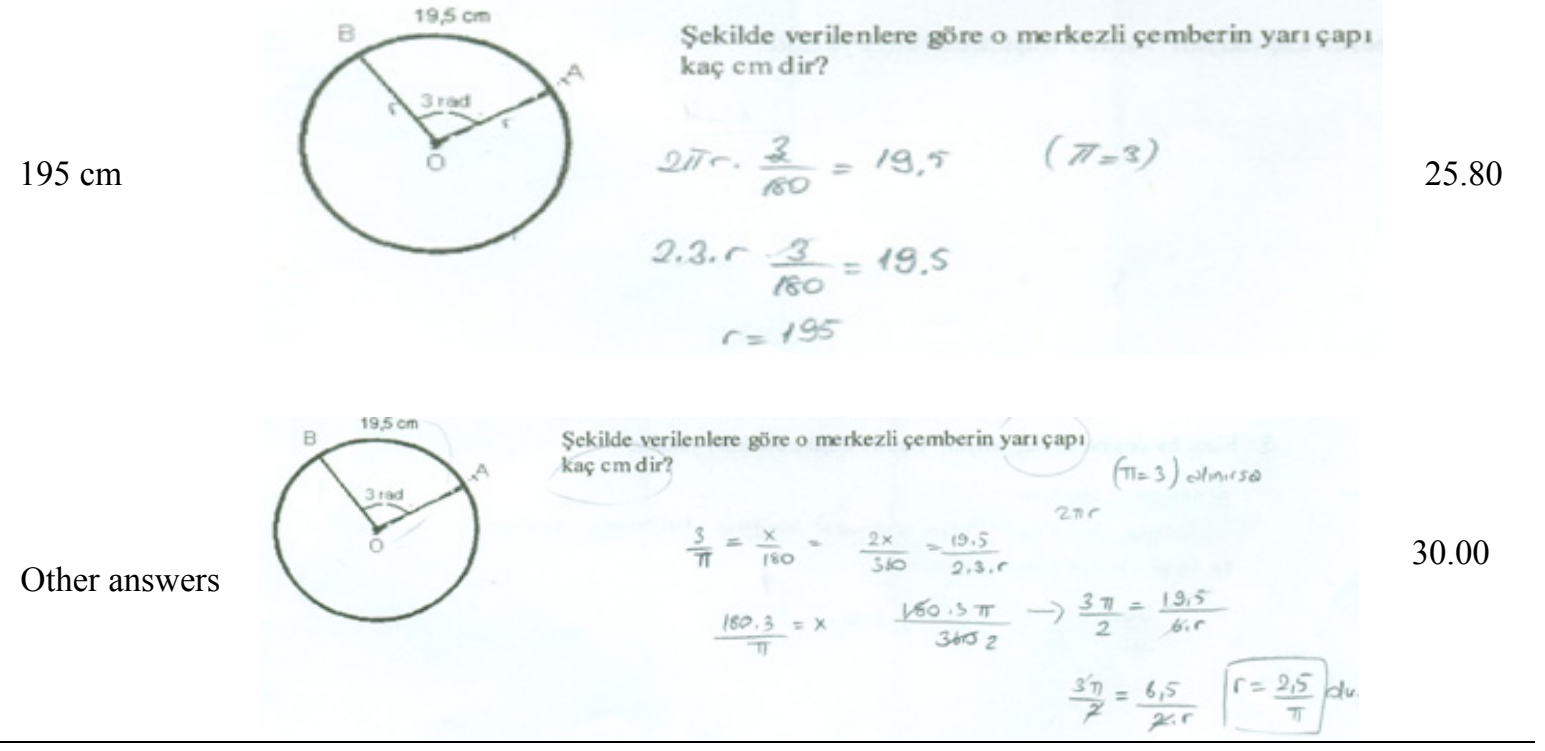

As is seen in the Table 4, only $14 \%$ of the prospective mathematics teachers found the length of radius correctly by giving the answer of " $6.5 \mathrm{~cm}$ " to the $4^{\text {th }}$ question which was prepared in order to measure the knowledge levels of the prospective mathematics teachers concerning radian. $31 \%$ of the prospective teachers found the length of radius as $13 \pi \mathrm{cm}$ by mistaking 3 radians as 3 degrees, $25 \%$ indicated it as $195 \mathrm{~cm}$, and $30 \%$ came up with other wrong values. The answers given to that question clearly show the deficiency of the conceptual knowledge of prospective mathematics teachers concerning the concept of radian. Although the measure of angle was given in terms of radian in the question, the prospective teachers preferred to find the result by taking it as an expression of degree.

\section{Conclusion and Discussion}

This study examined in written the knowledge levels of prospective mathematics teachers about the concepts of degree and radian that constitute the basis of trigonometry. Based on the research findings, it is concluded as follows:

- While $60 \%$ of the prospective mathematics teachers defined the concept of degree correctly, $40 \%$ made some incorrect definitions of the concept including "the angle between two straight lines", "the measure of the angle facing the unit length", etc. This shows that prospective mathematics teachers have not understood the concept of degree absolutely.

- Interestingly enough, only $8.6 \%$ of the prospective mathematics teachers were able to provide a correct definition of the concept of radian. Approximately $90 \%$ of the prospective mathematics teachers made such incorrect definitions of radian as, "The expression of degree in terms of $\pi$ ", "The unit of length of degree", and "I just know the formula of $\frac{D}{180}=\frac{R}{\pi}$, I do not know what radian is". This shows the deficiency of knowledge of prospective mathematics teachers concerning the concept of radian. It is remarkable that although the prospective teachers succeeded in the operations about radian, they did not know what that concept meant. During the interviews, the prospective teachers stated that although they wondered what radian was, they failed to reach the information about that concept. The statement of a prospective teacher in this matter is as follows: 
"I do not know exactly what radian is. As far as we have learnt, there is such relationship as $\frac{\boldsymbol{D}}{\mathbf{1 8 0}}=\frac{\boldsymbol{R}}{\boldsymbol{\pi}}$ between degree and radian. I do not know the reason for this relationship". Another statement on this subject is as follows: "Indeed, I am very curious about what radian is, but I have never seen an absolute definition of it anywhere so far. I just know that it contains some expressions with $\pi$ ”. The prospective mathematics teachers were seen to associate radian with " $\pi$ ". Another research finding is that when the value of any angle was given in terms of radian, the prospective mathematics teachers performed operations by mistaking that value as degree, and they failed to display the same performance as the one achieved with degree in radian. This demonstrates that the prospective teachers are more familiar with degree in comparison to radian. This result is reported by some other researchers, too (Steckroth, 2007; Akkoç, 2008).

- The literature review shows that students have considerable difficulty and misconception on the subject of trigonometry (Kendal \& Stacey, 1997; Orhun, 2000; Doğan, 2001; Demetgül, 2001; Kong, 2003; Weber, 2005; Martinen \& Siearre, 2005). It is probable that one of the most important reasons of this situation is that prospective teachers do not have a sufficient comprehension of the concepts of degree and radian that constitute the basis of trigonometry. It goes without saying that such knowledge deficiency will have a negative effect on the achievements of the students who are going to be taught by these prospective teachers in their professional lives (Even, 1988; Wilson, 1994).

Based on the research findings, the following recommendations are put forward:

Visual and exploratory activities should be arranged for students during the coverage of the subject of trigonometry in order to make them comprehend the concepts of degree and radian. Students should be made to understand well that the central angle facing the arc that is equal to radius in length in a circle is called 1 radian. They should be taught that the number of radians in a circle is 6.28 which can be found by writing 3.14 (approximate value) instead of $\pi$. This is important in terms of making students notice that radian is a concept different from $\pi$. Furthermore, students should be made to comprehend that real numbers may be expressed by radian through exercises including the calculation of degree which 1 radian corresponds to or the calculation of the degree which 3.14 radians correspond to. Then, students should be made to realize that $\pi$ radians $=180^{\circ}$

\section{References}

Akkoç, H. (2008). Pre-service mathematics teachers' concept images of radian. International Journal of Mathematical Education in Science and Technology, 39(7), 857 - 878. http://dx.doi.org/10.1080/00207390802054458

Akkoç, H., \& Akbaş Gül, N. (2010). Analysis of a teaching approach aimin at eliminating student difficulties with radian. Ankara University Journal of Faculty of Education Sciences, 43(1), 97-129.

Ball, D. L. (1991). Research on Teaching Mathematics: Making Subject-Matter Knowledge Part of the Equation. İn J. Brophy (Ed.), Advances in Research on Teaching(pp. 1-48). Reenwich, CT: JAI Press.

Dede, Y., Bayazit, İ., \& Soybaş, D. (2010). Prospective Teachers' Understanding of Equation, Function and Polynomial Concepts. Kastamonu University Journal of Education, 18(1), 67-88.

Demetgül, Z. (2001). Trigonometri konusundaki kavram yanılgllarının tespit edilmesi. Yüksek Lisans Tezi, KTÜ Fen Bilimleri Enstitüsü, Trabzon,1145.

Doğan, A. (2001). Genel liselerde okutulan trigonometri konularının öğretiminde öğrencilerin yanılgıları, yanlışları ve trigonometri konularına karşı Öğrenci tutumları üzerine bir araştırma. Selçuk Üniversitesi, Fen Bilimleri Enstitüsü, Matematik Anabilim Dalı, Doktora Tezi, Konya.

Durmuş, S. (2004). Matematikte öğrenme güçlüklerinin saptanması üzerine bir çalışma. Kastamonu University Journal of Education, 12(1), 125-128.

Even, R. (1992). The Inverse Function: Prospective Teachers' Use of Undoing. International Journal of Mathematical Education in Science and Technology, 23(4), 557-562.

Even, R. (1988). Pre-service teachers conceptions of the relationships between functions and equations. Paper 
presented at the Proceedings of the International Group for the Psychology of Mathematics Education XI (PME XII), Hungary.

Farah-Sarkis, F. (1999). Inservice in Libanon. In B. Jaworski, T.L. Wood, \& S. Dawson (Eds.), Mathematics Teacher Education: Critical International Perspectives (pp. 42-47). London: Falmer Press.

Fi, C. D. (2003). Preservice secondary school mathematics teachers' knowledge of trigonometry: Subject matter content knowledge, pedagogical content knowledge and envisioned pedagogy. Unpublished $\mathrm{PhD}$ Thesis, University of Iowa, Iowa, USA.

Kendal, M., \& Stacey, K.(1997). Teaching Trigonometry. Vinculum, 34(1), 4-8.

McMillan, J. H., \& Schumacher, S. (2010). Research in Education: Evidence-Based Inquiry. (7th ed.). Boston, MA: Pearson.

Orhun, N. (2004). Student's mistakes and misconceptions on teaching of trigonometry. Journal of Curriculum Studies, $32(6), 797-820$.

Sağlam, Z., Sevim, M., Yurtseven, T., Oğuz, T., Yıldırım, Y., \& Sağlam, A. (2007). Matematik 10. Sinıf Ders Kitabı. (2th ed.). Rotamat Basım, İstanbul.

Shulman, L. (1986). Those who understand: Knowledge growth in teaching. Educational Researcher, 15, 4-14. http://dx.doi.org/10.3102/0013189X015002004

Steckroth, J.J. (2007). Technology-enhanced mathematics instruction: Effects of visualization on student understanding of trigonometry. Unpublished $\mathrm{PhD}$ Thesis, University of Virginia, Virginia, USA.

Steer, J., Devila, M.A., \& Eaton, J. (2009). Trigonometry with year 8. Mathematics Teaching, 215, 6-8.

Tatar, E., Okur, M., \& Tuna, A. (2008). A Study determine learning difficulties in secondary mathemtics education. Kastamonu University Journal of Education, 16(2), 507-516.

Topçu, T., Kertil, M., Akkoç, H., Yılmaz, K., \& Önder, O. (2006). Preservice and in-service mathematics teachers' concept images of radian. Proceedings of the 30th International Conference on the Psychology of Mathematics Education (PME30)(Vol. 5, pp. 281 - 288). Prague, Czech Republic.

Watkins, C., \& Mortimore, P. (1999). Pedagogy: What do we know? İn P. Mortimore (Ed.), understanding pedagogy and its impact on learning(pp. 1-20). London: Paul Chapman Publishing Ltd.

Weber, K. (2005). Students' understanding of trigonometric functions. Mathematics education resarch, 17(3), 94-115. 